\title{
COMPARATIVE SERUM LEVELS OF AN ANTIFERTILITY OXAZOLIDINETHIONE (U-11634) IN RATS AND MONKEYS
}

\author{
ARLINGTON A. FORIST, JAMES E. STAFFORD AND \\ GORDON W. DUNGAN \\ Biochemical Research Division, The Upjohn Company, Kalamazoo, \\ Michigan, U.S.A.
}

(Received 14th March 1968)

5-( $\alpha, \alpha, \alpha$-Trifluoro- $m$-tolyloxymethyl)-2-oxazolidinethione, referred to as $\mathrm{U}$ 11634 (Youngdale, Duncan, Emmert \& Lednicer, 1966), is orally active as an antifertility agent in the rat (Duncan, Johnston \& Lyster, 1966) but not in the monkey (Meyer \& Wolf, personal communication). This difference could reflect differences in drug availability following oral administration or could be due to the mechanism of action of U-1 1634. Species-specific responses have been reported for the antifertility diphenylindenes (Duncan, Stucki, Lyster \& Lednicer, 1962; Duncan \& Lyster, 1962) and diphenyldihydronaphthalenes (Duncan, Lyster, Clark \& Lednicer, 1963). Accordingly, a comparison of drug availability based on serum drug levels has been made following oral administration of U-11634 to the rat and monkey.

Eight groups of five female Sprague-Dawley rats, each weighing 219 to $231 \mathrm{~g}$, were employed. One group served as a control. Each member of the other seven groups received $25 \mathrm{mg}$ of U-11634 as a crystalline suspension in $1 \mathrm{ml}$ of sterile aqueous $0.25 \%$ methylcellulose by stomach tube. At appropriate times (Table 1), blood was removed by heart puncture from ether-anaesthetized animals and serum collected. Two male cynomologous (Macaca irus) monkeys weighing 4 and $5 \mathrm{~kg}$, respectively, received $200 \mathrm{mg} / \mathrm{kg}$ of U-11634 as the crystalline powder in a gelatin capsule orally. At appropriate times (Table 1), blood was removed from the femoral veins and serum collected.

One-ml serum samples were mixed with $1 \mathrm{ml}$ of $0.1 \mathrm{~N}-\mathrm{NaOH}$ and extracted with $25 \mathrm{ml}$ of chloroform. Twenty-ml aliquots of the chloroform extracts were evaporated to dryness at room temperature and the resulting residues dissolved in $5 \mathrm{ml}$ of $95 \%$ ethanol for ultra-violet spectrophotometry. Serum drug concentrations were calculated from the observed absorbance at the 243-m $\mu$ maximum for U-11634, after correction for the response found for pre-treatment serum samples (serum blanks). Under these conditions, recovery of U-11634 from serum was quantitative $(98 \cdot 3 \pm 3.3 \%)$ and mean serum blanks found for rats and monkeys were equivalent to 3.2 and $2.4 \mu \mathrm{g}$ of $\mathrm{U}-11634 / \mathrm{ml}$, respectively.

Serum levels of U-11634 in rats and monkeys following oral administration are shown in Table 1. In the rat, peak levels were observed after 1 to $2 \mathrm{hr}$ and 
remained essentially constant over the interval 2 to $24 \mathrm{hr}$, indicating rapid absorption and very slow metabolism and/or excretion. Relatively slower absorption occurred in the monkey with 12 or more hr required to reach peak levels. This may reflect administration of the powdered material in contrast to the aqueous suspension used with the rats. As in the rat, a slow metabolism and/or excretion is indicated. Moreover, peak serum levels, based on dose, are similar to those observed in rats.

\section{TABLE 1}

COMPARATIVE SERUM LEVELS OF 5 - $(\alpha, \alpha, \alpha$-TRIFLUORO - $m$ - TOLYLOXYMETHYL) - 2-OXAZOLIDINETHIONE IN RATS AND MONKEYS FOLLOWING ORAL ADMINISTRATION

\begin{tabular}{|c|c|c|c|}
\hline \multirow{3}{*}{$\begin{array}{l}\text { Time } \\
(h r)\end{array}$} & \multicolumn{3}{|c|}{ Serum $U-11634$ levels $(\mu g / m l)$} \\
\hline & \multirow{2}{*}{ Rats* } & \multicolumn{2}{|c|}{ Monkeys $\uparrow$} \\
\hline & & No. 635 & No. 636 \\
\hline $\begin{array}{r}1 \\
2 \\
4 \\
6 \\
8 \\
12 \\
18 \\
24\end{array}$ & $\begin{array}{l}10 \cdot 0 \pm 1.0 \\
13.3 \pm 1.6 \\
14.2 \pm 2.5 \\
12 \cdot 8 \pm 1.5 \\
14.4 \pm 2.6 \\
15.8 \pm 2 \cdot 0 \\
10.0 \pm 1.3 \\
15.3 \pm 3.1\end{array}$ & $\begin{array}{l}10.4 \\
20.0 \\
29.2 \\
32.6 \\
33.0 \\
\\
14.7\end{array}$ & $\begin{array}{l}12 \cdot 7 \\
24 \cdot 6 \\
32 \cdot 7 \\
42 \cdot 4 \\
49 \cdot 4 \\
\\
50 \cdot 4\end{array}$ \\
\hline
\end{tabular}

* Data (mean \pm S.E.M.) have been normalized to a dose of $100 \mathrm{mg} / \mathrm{kg}$.

$\dagger 200 \mathrm{mg} / \mathrm{kg}$.

The data presented do not permit a kinetic analysis and calculation of the actual amounts of U-11634 absorbed. However, they do establish drug absorption with achievement of comparable serum levels in the rat and monkey. It is concluded, therefore, that lack of antifertility activity in the monkey reflects the mechanism of drug action rather than a species difference in drug absorption.

The authors are indebted to Dr R. L. Johnston and Mr R. S. Schwikert for assistance in the study with monkeys.

\section{REFERENCES}

Duncan, G. W., Johnston, R. L. \& LysteR, S. C. (1966) Inhibition of pregnancy with an oxazolidinethione. F. Reprod. Fert. 11, 85.

Duncan, G. W. \& Lyster, S. C. (1962) Effect of U-11555A on blastocyst development. Fedn Proc. Fedn Am. Socs exp. Biol. 21, 437.

Duncan, G. W., Lyster, S. C., Clark, J. J. \& Lednicer, D. (1963) Antifertility activities of two diphenyldihydronaphthalene derivatives. Proc. Soc. exp. Biol. Med. 112, 439.

Duncan, G. W., Stucki, J. C., Lyster, S. G. \& Lednicer, D. (1962) An orally effective mammalian antifertility agent. Proc. Soc. exp. Biol. Med. 109, 163.

Youngdale, G. A., Duncan, G. W., Emmert, D. E. \& Lednicer, D. (1966) Synthesis and antifertility activity of 5-(phenoxymethyl)-2-oxa-zolidinethiones. J. med. Chem. 9, 155. 